\title{
Implementing the Rights of the Child
}

\author{
Cees Hoefnagels ${ }^{1}$, Anna van Spanje ${ }^{1}$, Saskia Wijsbroek ${ }^{1}$ \\ ${ }^{1}$ Research Centre Social Innovation, HU University of Applied Sciences Utrecht, The \\ Netherlands.
}

\begin{abstract}
Although the 1989 United Nations Convention on the Rights of the Child (UN $C R C)$ has been ratified by almost all countries, and children's rights have been well documented, the rights of many children are neglected and violated on a daily basis. We propose to initiate several pilot projects and corresponding studies, followed by dissemination and implementation activities, in order to raise awareness of children's rights among youth professionals and children, and implement children's rights in professional practice.

We have some options and ideas to perform these research activities in the Netherlands, but we are looking for international partners so we can a) learn from previous experiences and b) accomplish that more people and organizations benefit from the projects and findings. At the 2019 CARPE conference, our aim is to find universities of applied sciences that have expertise on children's rights, and that are willing to collaborate with us on further developing and carrying out the proposed research.
\end{abstract}

Keywords: children's rights; child welfare; youth care. 


\section{Background}

Although almost all countries have ratified the United Nations Convention on the Rights of the Child (UN CRC) (United Nations Committee on the Rights of the Children, 1989), children's rights are ignored every day, including in Europe. Daily practice in health and youth care reveals that ignoring and violating children's rights appears to be rather the rule than the exception. This includes youth professionals who are willing or assume to act in the best interests of the child.

Across many social domains (in particular in health), a much heard complaint is that children do not feel taken seriously. Many decisions that will affect the child's life, for instance regarding family interventions in child abusive families, or being removed from their home, are indeed made by adults unilaterally without taking the child's opinion into consideration too frequently (Lansdown, 2011; also see UN CRC, art. 12; United Nations Committee on the Rights of the Children, 1989), and refrain the child from the right to oppose against the intervention.

It appears that on all levels in society people - children and adults, professionals and policymakers - are not (fully) aware of the UN CRC (National Youth Council, 2019; The Dutch NGO Coalition for Children's Rights, 2019). As most children and adults are unaware of children's rights, these rights are regularly ignored by their parents, youth professionals and other children in addition to society as a whole without knowing or acknowledging it. Therefore, the objective of this project is to change the current practice, to reverse the rule and the exception, and monitor the changes.

The UN Committee on the Rights of the Children (2013) describes what the convention and articles imply. For example, the General comment No. 14 describes what the right of the child to have his or her best interests taken as a primary consideration means. Article 3, paragraph 1, states: "In all actions concerning children, whether undertaken by public or private social welfare institutions, courts of law, administrative authorities or legislative bodies, the best interests of the child shall be a primary consideration." (United Nations Committee on the Rights of the Children, 2013, p.3).

Thus, the best interests of the child serve as a fundamental right, a principle and a rule of procedure. Later on, the importance of this right is being underlined: "Article 3, paragraph 1, of the Convention on the Rights of the Child gives the child the right to have his or her best interests assessed and taken into account as a primary consideration in all actions or decisions that concern him or her, both in the public and private sphere. Moreover, it expresses one of the fundamental values of the Convention. The Committee on the Rights of the Child (the Committee) has identified article 3, paragraph 1 , as one of the four general principles of the Convention for interpreting and implementing all the rights of the child, and applies it is a dynamic concept that requires an assessment appropriate to the specific context." (United 
Nations Committee on the Rights of the Children, 2013, p.3). These and other quotes show that children's rights have been put into words very well. Corresponding actions, however, are lacking.

In sum, although children's rights have been internationally officially recognized for 30 years, these rights are being ignored and violated every day, everywhere. With the proposed project, we aim to bring children's rights to the attention of both youth professionals and children, and implement children's rights in daily practice.

\section{Project proposal}

In order to reach the aforementioned goal, we have come up with several actions:

1) A series of pilot projects will be conducted in order to raise awareness and to implement children's rights in daily practice, among youth professionals and children.

2) These projects will be monitored through longitudinal multi-method (qualitative and quantitative) studies.

3) Networking conferences will be organized to a) design the pilot projects in the initial stage, and b) learn about the conditions in the final stages.

4) We will disseminate and implement the gained evidence.

\subsection{Possibilities in the Netherlands}

Focusing on recent initiatives in the Netherlands only, several options for pilot projects can be considered. One option for example, includes a process evaluation and an evaluation of the dissemination of two different Dutch approaches that both address the implementation of children's rights in primary education settings (schools) in the Netherlands and their results.

Another option is to assess to which extent youth professionals comply with / adhere to the recent developed standard procedure on reporting child abuse and neglect while acknowledging the rights of the child. The law that introduced the procedure was enacted in the Netherlands on January $1^{\text {st }}$ of this year. To this end a guide was developed (Geurts, Hokwerda, Bouma, Winder \& Hoefnagels, 2018) which should facilitate professionals to include the child's rights in their considerations and behavior, as a professional precondition when faced with a suspicion of child abuse and neglect.

In addition, there are plans to select some neighborhoods in the Netherlands in which researchers create conditions, install procedures and empower children and parents in order to make these neighborhoods child rights-proof over the next decade. We could contribute to and study these initiatives. 


\subsection{European collaboration through CARPE}

Even though there are several research possibilities in the Netherlands on the topic of children's rights, we would like to extend our plan to other countries. We believe that European collaboration will make our research more solid. Furthermore, the implementation of children's rights is important for children and youth professionals everywhere.

At the 2019 CARPE conference we will gather the existing, planned and potential projects across the participating universities of applied sciences. Based on the initiatives in these countries, the nature of the proposed pilot projects will be explored together. The proposed pilot projects will be discussed in order to select a set of complementary projects which serve the objectives most, including a maximum gain of evidence.

We are eager to hear about other initiatives on implementing children's rights, so we can learn from those experiences. Together with CARPE partners, we could either design new research projects or (adapt and) carry out projects that seem promising or have proven to be successful in other countries. Specific topics include but are not limited to homeless children, unaccompanied minors foreign nationals, and disappearance of children (see The Dutch NGO Coalition for Children's Rights, 2019, for more examples).

Besides collaboration with the universities of applied sciences that are joined in CARPE, we would also like to expand our network with other possible contributors, namely the organizations that CARPE universities are working with on the topic of children's rights. For example advocacy organizations (like Defence for Children, one of our current partners), health and youth care professionals, policy makers, and local governments could contribute to and benefit from the proposed project.

\section{References}

Geurts, E., Hokwerda, Y., Bouma, H., Winder, L. \& Hoefnagels, C. (2018). Handreiking 'Participatie van kinderen in de Meldcode huiselijk geweld en kindermishandeling'. Den Haag: Ministerie van Volksgezondheid, Welzijn en Sport.

Lansdown, G. (2011). Every child's right to be heard. A resource guide on the UN committee on the rights of the child General comment No. 12. London: The Save the Children Fund.

National Youth Council (2019). There to talk, dare to listen. Dutch youth on the children's rights treaty. Utrecht: NJR.

The Dutch NGO Coalition for Children's Rights (2019). Children's rights in the Netherlands: Input to the list of issues of the UN Committee on the Rights of the Child. Leiden: Kinderrechtencollectief.

United Nations Committee on the Rights of the Children (1989). Convention on the Rights of the Child. Available at: https://www.ohchr.org [accessed 5 July 2019].

United Nations Committee on the Rights of the Children (2013). General comment No. 14 on the right of the child to have his or her best interests taken as a primary consideration 
Cees Hoefnagels, Anna van Spanje, Saskia Wijsbroek

(art. 3, para. 1). CRC/C/GC/14. Available at: https://www.ohchr.org [accessed 5 July 2019]. 